\title{
MEMAHAMI AGRIBISNIS SYARIAH BERDASARARKAN PENDEKATAN SISTEM AGRIBISNIS
}

\section{U. Maman*}

\begin{abstract}
Abstrak
Islam telah mengatur seluruh komponen dari kegiatan manusia. Begitu pula dengan Agribisnis sebagai bagian dari kehidupan manusia. Namun agribisnis syariah tidak menangani masalah teknis seperti on-farm. Maka perlu dilakukan pembahasan agribisnis syariah yang bersifat solutif terhadap bebagai persoalan. Penelitian ini bertujuan memilah agribisnis berdasarkan subsistem agribisnis kemudian mendekatinya secara syar'i pada masing-masing subsistem. Metode ini menggunakan pendekatan analisis deskriptif. Dari hasil penelitian di simpulkan bahwa Agribisnis syariah menyetujui pemberian subsidi pengadaan saprotan sebagai bagian pengadaan pangan yang merupakan pemenuhan kebutuhan pokok warga negara yang menjadi tanggung jawab negara. Adanya konsepsi kepemilikan merupakan alternatif srategis bagi pengadaan dana yang diperlukan untuk memberikan subsidi bagi sektor pertanian, di mana dana tersebut dapat bersumber dari asset yang masuk kategori kepemilikan umum. Untuk setiap sub sistem agribisnis yang tidak terkait dengan ideologi atau keyakinan, maka konsepsi syariah memberikan keterbukaan untuk mengadopsi, mengembangkan, dan bekerjasama dengan berbagai pihak, baik muslim atau non-muslim. Dalam mengadopsi teori-teori yang netral, agribisnis syariah akan melakukan internalisasi kesadaran ketuhanan, sehingga sebuah teori yang netral dan keterampilan teknologis tidak kehilangan koneksitasnya dengan kesadaran ketuhanan. Maka kebijakan alternatif yang dapat diterapkan pembehanan konsepsi kepemilikan secara implementatif untuk menata asset-asset strategis yang bertujuan untuk kesejahteraan dan kemandirian petani. Dari dana kepemilikan umum, Pemerintah dapat mengembangkan SDM petani, penguatan kelembagaan petani, memperkuat riset kemandirian petani yang bertujuan untuk keamanan dan kedaulatan pangan. Pemerintah dapat memberikan subsidi dalam bentuk bantuan permodalan pada petani yang sudah terbina, SDM-nya maupun kelembagaannya, dan memperkuat aspek-aspek penunjang sistem agribisnis yang ditopang oleh SDM petani dan pendanaan yang memadai.
\end{abstract}

Kata kunci : Penerimaan, koreksi \& teori subtitusi, dan internalisasi keimanan

\section{ABSTRACT}

Agribusiness as a system which is consist of at least four sub systems actually can be divided based on the process of the formulation theory and it connection with ideology, faith, culture, and material or benefit intrest -into three categories. First, the theories which are directly or indirectly as an ideology elaboration. Second, the scientific theories influenced by faith, 
ideology, or at least by culture and benefit intrest; and the third is the scientific theory gained by direct observation or lab instrument which does not have any relation with faith. Based on the light of this facts, the shariah agribusiness sugests four stgategic stapes: "fixcation" that means accepting the neutral theory or skill technology; correction of unrelevant theory with Islamic shariah; substitution of wrong theory in shariah perspective, and internalization of faith conciousness to the all neutral theories or skill technologies. The four strategies beside presenting alternatives ways of agricultural develpment, also makes the developments are based on spiritual faith.

Key words: acceptance, correction \& substitution theory, and internalization of faith

\section{PENDAHULUAN}

Ketika berbicara tentang agribisnis syariah, yang menjadi pertanyaan mendasar adalah apa yang membedakan agribisnis syariah dengan agribisnis non-syariah. Pertanyaan ini semakin menggelitik ketika pertanian dipahami sebagai kegiatan teknis budidaya, $p$ engolahan hasil, efisiensi input untuk menghasilkan produk yang berkualitas dengan kuantitas yang cukup banyak. Jika agribisnis hanya menyangkut masalah teknis, di manakah posisi agribisnis syariah? Adakah cara mengolah tanah, cara menanam, cara memupuk, cara melakukan penyerbukan yang bersifat syar'i?

Ketika Islam tidak mengatur masalah-masalah teknis yang terkait dengan on-farm, maka tidak terdapat perbedaan prinsipil antara agribisnis syariah dengan agribisnis konvensional. Dari sini tidak mustahil akan muncul kesimpulan bahwa sesungguhnya tidak terdapat konsep agribisnis syariah; bahkan agribisnis syariah merupakan pembahasan yang tidak perlu. Pembahasan agribisnis syariah hanya sensasi untuk mendisvaritas antara syariah dan non-syariah karena pembahasan syariah sedang menjadi trend dalam aspek ekonomi seperti perbankan dan asuransi syariah versus konvensional.

Pertanyaan lainnya juga cukup menggelitik ketika agribisnis dipahami sebagai aktivitas pengelolaan usaha tani, seperti perencanaan tanam, menghitung kebutuhan pasar untuk menjaga keseimbangan penawaran dan permintaan, dan memposisikan keunggulan suatu wilayah dalam menghasilkan sebuah produk pertanian unggulan. Hal ini pun bersifat netral, tidak terdapat perbedaan aspek manajerial tersebut antara agribisnis syariah dengan agribisnis konvensional. Lagi-lagi hal ini pun akan membawa pada kesimpulan bahwa pembahasan agribisnis syariah tidak perlu.

Belakangan ini juga muncul pembahasan agribisnis syariah yang menyingkap rahasia Allah dalam penciptaan berbagai ragam hortikultura, makanan pokok, penciptaan tanah, air, dan proses munculnya hujan, seperti dilakukan Said dan Pratiwi (2005). Penyingkapan rahasia Allah ini menimbulkan bercak kekaguman yang luar biasa atas kemahabesaran Allah SWT. Namun pemba-hasan ini hanya berhenti pada kekaguman, tidak menyelesaikan berbagai persoalan pembangunan pertanian. Padahal syariah Islam bersifat praktis, memecahkan berbagai persoalan kemanusiaan, baik dalam ekonomi, soaial, maupun politik. Atas hal demikian, perlu adanya pembahasan agri-bisnis syariah yang bersifat solutif terhadap berbagai persoalan. Artikel ini akan mencoba memilah agribisnis berdasarkan sub sistem agribisnis, kemudian mendekatinya secara syar'i pada mas-ing-masing sub sistem. 


\section{Memilah Teori-Teori Sosial Ekonomi Modern:}

\section{Sebuah Kerangka Penalaran}

\begin{abstract}
Teori sosial ekonomi modern ditinjau dari keterkaitannya dengan ideologi, keyakinan, kelekatan kultural, dan muatan kepentingan yang terkandung padanya seakan-akan berada dalam sebuah garis kontinum yang tidak memiliki batas yang jelas. Pada ujung paling kanan teori tersebut merupakan sebuah elaborasi ideologis dan keyakinan, sedangkan pada ujung paling kiri teori-teori tersebut merupakan hasil pengamatan yang bersifat laboratoris, atau bahkan sebuah keterampilan teknologis yang sangat netral. Di samping itu, pernyataan sebuah teoritis seringkali memuat kepentingan yang beririsan dengan ideologi, keyakinan, atau bahkan kepentingan yang bersifat material. Antara netralitas sebuah teori dengan ketidaknetralannya tidak memiliki batasan yang jelas, seperti ilustrasi pada Gambar 1.
\end{abstract}

Atas hal demikian, mengacu pada sosiolog klasik Peter R.Berger, seperti diungkapkan Sunarto (1993), para ilmuan hendaknya tidak hanya percaya pada tembok bagian depan, tetapi harus memahami apa yang ada di balik tembok tersebut. Indahnya bertutur kata calam mengungkapkan sebuah teori, menurut Berger, seringkali menyimpan sebuah kepentingan. Karena itu, Berger menyarankan agar para ilmuan pandai mengungkap tabir dan memahami motifmotif terselubung di balik sebuah pertanyataan teoritis (debunking motive), baik motif yang bersifat ideologis maupun kepentingan materi. Sejalan dengan pernyataan Berger, sebagai upaya untuk memahami agribisnis syariah, maka setiap pernyataan teoritis harus dipilah menjadi tiga kategori berdasarkan proses kemunculannya serta keterkaitannya dengan ideologi atau keyakinan; serta berdasarkan muatan kepentingan, etnosentrisme, dan kelekatan budaya dalam teori-teori tersebut. Pilahan-pilahan tersebut adalah sebagai berikut.

Pertama, kita harus membedakan teori yang merupakan hasil pemikiran yang bersifat normatif dan terkait atau memancar dari sebuah keyakinan, dengan teori-teori ilmiah yang meru-pakan hasil dari pengamatan yang bersifat laboratoris. Dengan kata lain, kita harus membedakan antara teori yang merupakan sikap seseorang terhadap fakta dengan fakta itu sendiri. Hasil pemikiran tentang suatu obyek atau sikap terhadap suatu obyek akan melahirkan kesimpulan yang bersifat ideologis, yakni akan menghasilkan teoriteori ilmiah yang sarat dengan nilai atau keya-kinan. Ketika Kenneth Minogue mendefinisikan kapitalisme sebagai "Yang dikerjakan oleh orang banyak ketika Anda membiarkan mereka berbuat sekehendak hati" (Bremmer, 2011), maka dia sedang berpikir dan memandang manusia sebagai entitas otonom yang dapat berbuat sesuai kehendak mereka, tanpa harus mengacu pada norma-norma religi.

Pernyataan tersebut lebih merupakan pernyataan ideologis yang penuh dengan muatan keyakinan, dibanding sebagai sebuah pernyataan teoritis yang netral dan obyektif. Namun banyak juga teori-teori modern yang netral -- atau setidaknya hanya memiliki irisan kecil dengan keyakinan idelogis. Sebagai gambaran, selama tahun 1961 sampai tahun 1984, di AS - menurut catatan Vernon Katz (1992) - terdapat sepuluh buah penelitian besar yang berusaha melihat pengaruh kebutuhan berprestasi (need for achievement) pada keberhasilan seseorang atau seke-lompok orang pada berbagai bidang profesi. Dari sepuluh penelitian tersebut, tujuh penelitian menunjukkan adanya korelasi antara skor "an-ach" (need for achievement) dengan kinerja profe-sionalitas dan keberhasilan wirausaha. Penelitian-penelitian tersebut bermula dari dan mengacu pada tesis klasik McClelland bahwa tingginya " $n$-ach" 
merupakan faktor bagi keberhasilan berwirausaha.

Namun, sekalipun bertolak dantermotivasi oleh sudut pandang capital menghasilkan kesimpulan ilmiah yang netral, dan berlaku lintas agama dan budaya bahwa keinginan berprestasi merupakan fungsi bagi keberhasilan dalam berbagai bidang kehidupan. Atas hal demikian, sekalipun terdapat irisan antara satu teori dengan teori lain, atau antar unsur-unsur sebuah teori, seorang ilmuan harus jeli memilah antara kesimpulan-kesimpulan ilmiah yang bernuansa ideologis dengan kes-impulan-kesimpulan ilmiah yang netral dan universal.

Kedua, kita juga harus memilah secara seksama antara teori yang merupakan pola pengaturan kehidupan yang bernuansa ideologis dan keyakinan dengan pola-pola pengaturan kehidupan sosial ekonomi yang merupakan teori-teori ilmiah yang netral.

Secara faktual, apa yang disebut sebagai teori-teori ilmiah - khususnya dalam teori sosial ekonomi modern seringkali merupakan sistem kehidupan, yakni pola-pola pengaturan ekonomi dan sosial yang memancar dari sebuah pemikiran, ideologi, budaya atau bahkan keyakinan. Bremmer mengilustrasikan, ketika Adam Smith menulis dalam bukunya, The Theory of Moral Sentiments (1759), bahwa manusia pada dasarnya sering tertarik pada kekayaan orang lain, dan karena itu kebahagiaan harus diserahkan kepada manusia itu sendiri, maka ia sedang berusaha meletakkan dasar pola pengaturan kehidupan yang diserahkan kepada manusia untuk mengatur dirinya sesuai kehendaknya.

Atas hal demikian, menurut kapitalisme, nilai manfaat sebuah benda dan kebolehan me-manfaatkannya sepenuhnya tergantung pada kesukaan manusia. Manusia memiliki kebebasan untuk memililiki apa pun yang ia kehendaki. Sebesar apa pun kualitas dan kuantitas materi yang mampu ia miliki, sepenuhnya tergantung pada manusia. Manusia boleh melakukan cara apapun untuk memililiki benda, tergantung pada kesepakatan di antara mereka - atau lebih tepatnya tergantung pada kelompok-kelompok kepentingan yang memiliki kemampuan kapital dan politik untuk mendorong - atau bahkan memanipulasi —bagi terjadinya kesepakatan di antara manusia.

Juga merupakan pengaturan kehidupan ketika John Maynard Keynes melakukan kritikan tajam terhadap Liberalisme Adam Smith, dan menyarankan agar negara campur tangan secara langsung untuk mengatur kehidupan ekonomi.

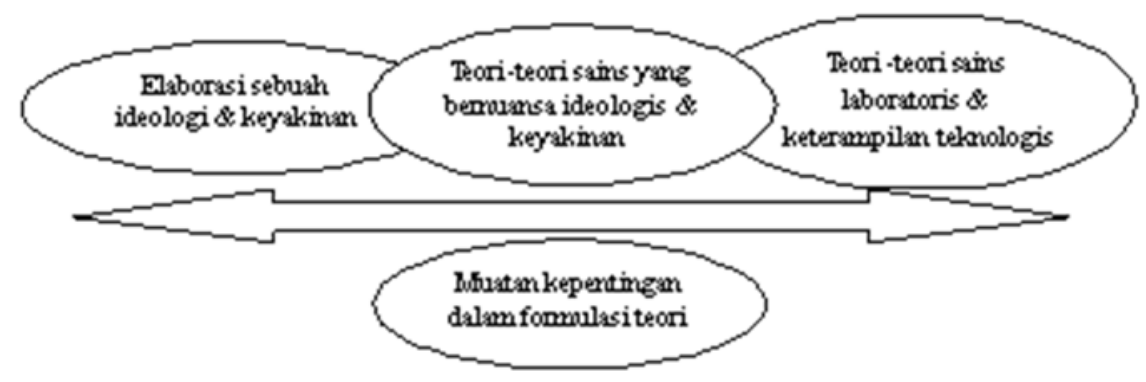

Gambar 1. Ilustrasi keterkaitan sebuah teori dengan ideologi dan keyakinan 
Sebaliknya, menurut kaum Neoliberalisme -yang muncul pasca Keynesian -Pemerintah tidak boleh campur tangan dalam kehidupan sosial ekonomi. Melalui lembaga-lembaga internasional (seperti IMF, World Bank, dan WTO) sebagai pengusung "ideologi neo-liberal," kaum neoliberal menyarankan swastanisasi sektor-sektor strategis, pengurangan subsidi sektor publik, seperti subsidi BBM, pangan dan saprotan.

Ketiga, kita harus mengkritisi teoriteori ilmiah yang tampak netral dan obyektif, akan tetapi sesungguhnya teoriteori tersebut mengandung nilai dan kepentingan, terutama kepentingan penguasaan asset-asset strategis oleh berbagai perusahaan multinasional, seperti halnya ideologi anti subsidi yang diemban IMF, untuk mengontrol perdagangan dalam rangka memperoleh keuntungan materi yang besar.

\section{Memilah Berbagai Sub Sistem Agribisnis}

$$
\text { Mengacu pada Wikipedia }
$$

(dikunjungi, 4 Agustus 2014), istilah agribisnis diserap dari bahasa Inggris: agribusiness. Istilah ini merupakan portmanteau dari agriculture (pertanian) dan business (bisnis). Dalam bahasa Indonesia dikenal pula varian anglisismenya: agrobisnis. Dengan kata lain, agribisnis secara harfiah berasal dari kata agri dan bisnis. Penggabungan keduanya bermakna: segala kegiatan usaha produktif di sektor pertanian atau sektor-sektor yang terkait dan menopang sektor pertanian.

Di Indonesia, istilah agribisnis diperkenalkan pada tahun 1980-an sebagai upaya untuk merombak pola bertani tradisional menjadi pertanian modern yang berorientasi pasar, bersifat komersial dan mengadopsi pola-pola manajemen modern, termasuk mengadopsi teknologi yang diperlukan.

Agribisnis hakikatnya adalah bisnis berbasis usaha pertanian atau bidang lain yang mendukungnya, baik di sektor hulu maupun di hilir. Penyebutan "hulu" dan "hilir" mengacu pada pandangan pokok bahwa agribisnis bekerja pada rantai sektor pangan (food supply chain). Agribisnis, dengan perkataan lain, adalah cara pandang ekonomi bagi usaha penyediaan pangan.

Sebagai subyek akademik, agribisnis mempelajari strategi memperoleh keuntungan dengan mengelola aspek budidaya, penyediaan bahan baku, pascapanen, proses pengolahan hingga tahap pemasaran. Obyek agribisnis dapat berupa tumbuhan, hewan ataupun organisme lainnya. Kegiatan budidaya merupakan inti (core) agribisnis meskipun suatu perusahaan agribisnis tidak harus melakukan sendiri kegiatan ini.

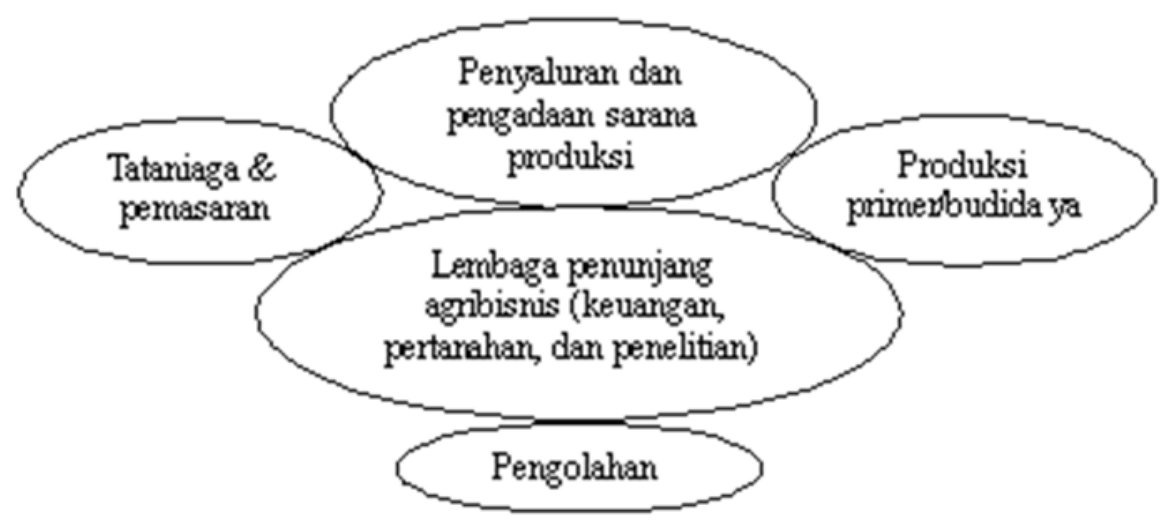

Gambar 2. Agribisnis sebagai sistem 
Dalam perspektif makro, agribisnis merupakan sebuah sistem yang menopang ekonomi nasional (PDB, kesempatan berusaha dan pertumbuhan ekonomi).

Sistem yang dimaksud mengandung arti pola pengaturan komunitas dan masyarakat; seperti sistem sosial, sistem ekonomi, sistem politik, dan sistem komunikasi. Sistem sering dibangun berdasarkan kesepakatan-kesepakatan (atau karena tekanan), baik tertulis maupun tidak tertulis. Kesepakatan atau tekanan sering merupakan perwujudan dari sebuah ideologi, seperti Kapitalisme dan Sosialisme.

Sebagai sebuah sistem, dengan mengacu pada Said dan Intan (2001), maka agribisnis setidaknya terdiri dari empat sub sistem yang terkait satu sama lain, yakni: (1) sub sistem budidaya; (2) penyaluran dan pengadaan sarana produksi, seperti pengadaan pupuk; (3) pengolahan pascapanen, (4) tananiaga dan pemasaran, dan (5) lembaga-lembaga penunjang

agribisnis, seperti masalah pertananahan, lembaga keuangan, dan penelitian, seperti disajikan pada Gambar 2.

Mengacu pada kerangka penalaran yang sudah disebutkan di atas, maka berbagai sub sistem agribisnis tersebut dapat dibagi menjadi tiga bagian besar ditinjau dari keterkaitannya dengan ideologi, keyakinan, dan kepentingan. Pertama, terdapat unsur unsur dalam sub sistem agribisnis yang netral, yakni tidak terkait dengan ideologi atau kepentingan. Kedua, terdapat unsur sub sistem agribisnis yang lekat dengan keyakinan, ideologi, budaya, dan kepentingan. Ketiga, terdapat unsur sub sistem yang netralk tetapi sesungguhnya di situ terkandung kepentingan material.

Sub sistem budidaya, seperti pemupukan, dan perlindungan tanaman merupakan ketrampilan teknis yang netral. Islam tidak mengatur masalah-masalah teknis tersebut. Ketika seorang penyuluh pertanian menganjurkan untuk menggunakan bibit padi tertentu, melakukan pemupukan, dan menggunakan pestisida jika diperlukan, maka pernyataan tersebut tampak sangat netral, dan sematamata membantu petani untuk meningkatkan hasil panennya. Namun bagi perusahaan multinasional kapitalistik, anjuran inovasi budidaya pertanian, seperti pemupukan dan penggunaan perstisida menjadi ajang pencarian keuntungan. Sejak Revolusi hijau di tahun 1970-an dengan melakukan desiminasi inovasi budidaya pertanian, Everet M. Rogers (1989) yang mengumpulkan sejumlah tulisan dalam perspektif kritis, sudah melihat adanya kepentingan perusahaan multinasional untuk mencari keuntungan di balik kampanye adopsi inovasi sebagai trend dalam revolusi hijau. Pengadaan pupuk, bibit, dan pestisida menjadi ajang bisnis yang sangat menggiurkan, sehingga anjuran inovasi mengandung bias kepentingan.

Seakan-akan membuktikan kekhawatiran Rogers, mengacu para uraian Strahm (1999) bahwa sepuluh perusahaan besar yang mendominasi pasar pestisida menguasai $60 \%$ pasar pestisida dunia. Mereka mengambil keuntungan dari program bantuan pertanian FAO, Bank Dunia dan bank-bank pembangunan regional lainnya. Mereka yang terorganisir dalam sebuah badan bernama "Industry Cooperative" (ICP) mempunyai lobi-lobi berpengaruh atas kebijakan pertanian FAO. Industri pertanian negara-negara maju berkepentingan agar negara-negara berkembang menerima bibit-bibit unggul yang mereka tawarkan (yang tidak dapat berkembang tanpa penggunaan pupuk dan pestisida). Perusahaan-perusahaan besar yang memproduksi bahan kimia dan makanan menguasai pembibitan dan perdagangan bibit unggul. Di antaranya adalah Ciba-Geigy, Monsanto, Pfizer, Upjohn, Sandoz, Shell, Cargill, ITT, General Foods. Sebagai perusahaan yang bergerak di bidang saprotan, mereka 
tentunya berkepentingan untuk mencari keuntungan di balik kampanye inovasi pertanian dan revolusi hijau. Karena itu, para penulis Amerika Latin, seperti Bordenave (dalam Rogers, ed., 1989) mengingatkan bahaya bias pro inovasi dan bias-bias kepentingan dalam setiap kampanye inovasi.

Mengenai sub sistem pengadaan sarana produksi, hal ini tidak lepas dari sebuah ideologi dalam pengaturan masyarakat. Demikian halnya sub sistem penunjang agribisnis, seperti pengelolaan kepemilikan pertanahan, seperti konsep landreform. Dalam perspektif kaun neoliberal, Pemerintah hendaknya tidak memberikan subsidi bagi pembangunan pertanian, seperti diimplementasikan dalam nasehat-nasehat dan kebijakan IMF terhadap negara-negara berkembang. Sedangkan bagi pandangan Keynesian, subsidi merupakan sebuah keharusan untuk mencapai negara kesejahteraan (welfare state).

Namun sangat kontradiksi ketika IMF menuntut pengurangan subsidi di sektor pertanian; padahal negara-negara OECD mensubsidi sektor pertanian dengan jumlah sangat signifikan, untuk menjaga ketahanan dan kedaulatan pangan mereka. Mengacu pada uraian Holid (2011), pada tahun 2002 Jepang, Amerika Serikat dan Uni Eropa mensubsidi sebesar \$16 miliar untuk para produsen beras. Pada tahun 2003 pemerintah AS merogoh $\$ 1,3$ miliar untuk subsidi padi,

yang menelan biaya $\$ 1,8$ miliar untuk memanamnya. Artinya, pemerintah AS menutup biaya produksi padi sebesar 72 persen. Lebih rinci, tahun 2000 dan 2003, untuk menanam dan menggiling satu ton beras, AS mengeluarkan biaya sekitar $\$ 415$. Lalu beras tersebut diekspor seharga \$274 perton (34 persen di bawah harga nonsubsidi).

Gambaran lain, pada tahun 2002, Negara-negara OECD (30 negara) menghabiskan US\$ 311 miliar untuk subsidi pertanian. Negara-negara Uni Eropa (EU) mensubsidi para petani gula 50 euro untuk setiap ton tanaman penghasil gula (sama dengan $\operatorname{Rp~850,000/ton,~dengan~kurs~}$ Rp 17,000). UE juga mensubsidi sebesar US\$913 (sama dengan Rp 8,217,000) perkepala sapi kepada para peternak. Presiden G.W Bush pada Mei 2002 menandatangani Farm of Bill yang memuat subsidi sebesar US\$180 miliar, setara dengan Rp 162 triliun (patokan kurs Rp 9000/US\$) dalam tempo 10 tahun. India di tahun 2012 memberikan subsidi sektor pertanian sebesar 280-950 miliar rupee atau setara dengan US \$5,3 miliar untuk biaya produksi aneka ragam pangan dan membantu rumah tangga rawan pangan.

Karena itu, tidak bisa disangkal bila terdapat sinyalemen bahwa Pemerintah lebih tunduk pada nasehat IMF dan melindungi kepentingan asing dari pada melindungi rakyatnya sendiri. Dalam konteks ini, Alex Callinicos mengingatkan, bahwa "Musuh bukanlah globalisasi, namun kapitalisme global." Mengacu pada uraian Held, McGrew dan kawan-kawan, Callinicos (2011) mengungkapkan bahwa operasi perusahaan-perusahaan multinasional merupakan pusat globalisasi ekonomi. Pada tahun 1998 terdapat 53 ribu perusahaan multinasional dengan 450 ribu cabang-cabang asingnya dengan tingkat penjualan mencapai 9,5 triliun dollar AS. Mereka menguasai dua pertiga perdagangan dunia. Sepertiganya dibagi dengan transaksi-transaksi antara cabang-cabang perusahaan yang sama.

Dengan adanya berbagai sub sistem agribisnis yang lekat dengan sebuah ideologi dan adanya kepentingan berbagai pihak, maka yang menjadi pertanyaaan adalah bagaimana posisi agribisnis syariah dalam relung-relung ideologi kapitalis dan lautan kepentingan tersebut? Agribisnis syariah dalam konteks ini merupakan kritisisme ideologi berbasis spiritual, yang sekaligus memberikan alternatif solusi 
pembangunan pertanian. Berikut penedekatan syariah terhadap berbagai sub sistem agribisnis.

\section{Pendekatan Syariah terhadap Setiap Sub Sistem Agribisnis}

Kata syariah merupakan pengindonesiaan dari kata Arab, yakni assyarî'ah. Secara etimologis, kata assyarî'ah mempunyai konotasi masyra'ah al-mâ' (sumber air minum). Orang Arab tidak menyebut sumber tersebut dengan sebutan syarî'ah, kecuali jika sumber tersebut airnya berlimpah dan tidak pernah kering. Dalam bahasa Arab, syara'a berarti nahaja (menempuh), awdhaha (menjelaskan) dan bayyana al-masâlik (menunjukkan jalan). Syara'a lahumyasyra'u-syar'an berarti sanna (menetapkan). Syariah dapat juga berarti madzhab (mazhab) dan tharîqah mustaqîmah (jalan lurus).

Dalam istilah syar'i, syarî'ah berarti agama yang ditetapkan oleh Allah SWT untuk hamba-hamba-Nya yang terdiri atas berbagai hukum dan ketentuan yang beragam.

Hukum-hukum dan ketentuan tersebut disebut syariah karena memiliki konsistensi atau kesamaan dengan sumber air minum yang menjadi sumber kehidupan bagi makhluk hidup. Dengan demikian,

Tabel 1. Matrik Pendekatan Agribisnis Syariah terhadap Sub Sistem Agribisnis

Kategori teori dalam perspektif agribisnis syariah

\begin{tabular}{lcccc}
\hline & \multicolumn{3}{c}{ Kategori teori dalam perspektif agribisnis syariah } \\
\cline { 2 - 5 } Pendekatan & $\begin{array}{c}\text { Teori yang } \\
\text { netral }\end{array}$ & $\begin{array}{c}\text { Teori yang } \\
\text { bermuat-an } \\
\text { ideologi }\end{array}$ & $\begin{array}{c}\text { Teori-teori } \\
\text { sistem } \\
\text { kehidup-an }\end{array}$ & $\begin{array}{c}\text { Teori-teori } \\
\text { ilmiah yang } \\
\text { bermuat-an } \\
\text { kepen-tingan }\end{array}$ \\
\hline $\begin{array}{l}\text { Menerima } \\
\text { Memasukan Kesadaran }\end{array}$ & Ya & Tidak & Tidak & Tidak \\
Ketuhanan & Ya & Tidak & Tidak & Tidak \\
Mengoreksi & Tidak & Ya & Ya & Ya \\
Mengganti & Tidak & Ya & Ya & Ya \\
\hline
\end{tabular}

syariah dan agama mempunyai konotasi yang sama, yaitu berbagai ketentuan yang ditetapkan oleh Allah bagi hamba-hambaNya.

Kata syariah sering disandingkan dengan kata Islam sehingga menjadi syariah Islam. Kata al-Islâm (Islam), secara etimologis memiliki konotasi inqiyâd (tunduk) dan istislâm li Allâh (berserah diri kepada Allah). Istilah tersebut selanjutnya dikhususkan untuk menunjuk agama yang disyariahkan Allah SWT kepada Nabi Muhammad saw. Dalam konteks inilah, Allah menyatakan kata Islam sebagaimana termaktub dalam firman-Nya:

"Hari ini Aku telah menyempurnakan untuk kalian agama kalian, mencukupkan nikmatKu atas kalian, dan meridhai Islam sebagai agama bagi kalian" (QS al-Maidah [5]: 3).

Atas hal demikian, agribisnis syariah berarti pola pengaturan dan perencanaan pembangunan pertanian yang didasarkan pada syariah Islam yang berbasis akidah Islam. Ketika agribisnis syariah berhadapan dengan berbagai teori sosial ekonomi Barat - yang sarat dengan nilai-nilai ideologi sekuler dan kepentingan material-, maka agribisnis syariah setidaknya menawarkan lima pendekatan terhdap setiap sub sistem agribisnis, seperti disajikan pada Tabel 1 


\begin{tabular}{lllll}
\hline Membangun teori baru & Ya & Ya & Ya & Ya \\
\hline
\end{tabular}

Pertama, untuk sub sitem agribisnis yang bersifat ketrampilan yang bersifat netral dan obyektif, tidak ada alternatif lain kecuali menerima dan mengembangkannya. "Menerima" memiliki arti luas, yakni kesiapan mempelajari, memperdalam, berguru, dan bekerjasama dengan berbagai pihak yang memiliki kegiatan yang sama. Dalam hal ini agribisnis syariah memiliki sikap yang sangat inklusif, terbuka terhadap pihak lain.

Untuk sub sitem agribisnis yang bersifat teknis dalam manajemen kontemporer —seperti budidaya, teknik panen, pengemasan, pengolahan pascapanen, dan pemasaran -- kita harus membuka diri untuk belajar dari berbagai pihak. Demikian halnya untuk perencanaan dan membaca peluang pasar, serta menghitung kebutuhan akan produk, kita harus belajar dengan cermat, sehingga akan tercapai keseimbangan (equilibrium) antara penawaran produk dengan kebutuhan pasar akan produk tersebut.

Kedua, bagi agribisnis syariah bukan hanya menerima teori-teori yang netral tesebut melainkan harus segera memasukkan kesadaran ketuhanan. Ketika positivisme berusaha menghilangkan aspek spiritual dari setiap fenomena alam dan fenomena sosial, maka para ilmuan muslim harus segera memasukkan kembali kesadaran ketuhanan yang hilang itu. Karena itu, bagi para ilmuan muslim, realitas empiris bukan hanya menjadi obyek sains yang dapat menghasilkan kesimpulan dan teori-teori ilmiah yang netral dan obyektif, melainkan merupakan sebuah proses untuk menyadari keberadaan Allah; mengapresiasi kebesaran-Nya; serta urgensi penerapan hukum-hukum Allah dalam berbagai aspek kehidupan, termasuk dalam budiya pertanian.
Bagi seorang ilmuan sekuler, kajian morpologi dan pitobiologi, yakni kajian tentang proses munculnya rasa dan bau dalam tumbuhan merupakan hal empiris yang seakan-akan tidak terkait dengan Tuhan. Namun bagi ilmuan muslim, seperti tampak dalam uraian Fahd (1996), proses munculnya rasa dan bau ternyata memiliki keunikan yang tidak bisa diciptakan oleh manusia, melainkan sangat tergantung pada penciptaan. Karena itu, sekalipun banyak mengacu pada buku Nabataen Agriculture yang merupakan karya Syria Kuno, seorang penulis muslim memberikan judul pada bukunya "Kitab Sirr al-Khaliqo wa Sun'at Thabi'a" yang berarti rahasia pencipta dan penciptaan. Dengan demikian, agribisnis syariah melakukan internalisasi kesadaran ketuhanan pada teori-teori sains yang netral.

Ketiga, melakukan koreksi terhadap teori-teori yang berada pada susb sistem agribisnis yang tidak sesuai dengan Islam, tetapi dari segi konten sebagian masih bisa dipakai. Teori-teori kapitalis, misalnya, sangat konsern dengan kebebasan kepemilikan. Setiap individu bebas memiliki

kekayaan tanpa adanya batasan kuantitas dan kualitas. Sebaliknya, banyak sudut pandang sosialis yang menolak atau membatasi kepemilikan individual secara kuantitas, seperti kepemilikan tanah dengan konsep land reform.

Lalu, kita melakukan koreksi atas dasar konsepsi Islam tentang kepemilikan. Mengacu pada uraian An-Nabhani (Edisi Revisi, 2004) bahwa Islam membedakan kepemilikan menjadi tiga kategori, yakni kepemilikan individu, kepemilikan umum, dan kepemilikan negara. Kebebasan kepemilikan terbatas pada kategori kepemilikan individu, tidak berlaku bagi 
kepemilikan umum dan kepemilikan negara. Tegasnya, Islam memberikan kebebasan kepemilikan, termasuk mengembangkan dan bersaing dalam mengembangkannya. Hanya saja individu tidak boleh menguasai asset yang masuk kategori milik umum (seperti barang tambang dalam jumlah besar, hutan, dan asset yang menjadi kepentingan umum) dan milik negara. Kepemilikan umum merupakan faktor bagi kesejahteraan dan pemerataan, di mana individu-individu tidak boleh menguaai kepemilikan umum; harus dikelola oleh negara, dan negara pun tidak mengambil keuntungan; semuanya dikembalikan kepada rakyat.

Demikian halnya Islam tidak membatasi luasan pemilikan tanah bagi individu, tetapi individu harus mengelolanya dengan biaya sendiri, dan dilarang untuk menyewakannya atau melakukan bagi hasil atas tanah (yang berbau penyewaan tanah), sehingga tidak akan terjadi penumpukan penguasaan tanah di tangan seseorang, sehingga tidak akan membentuk tuan tanah. Dengan perkataan lain, Islam tidak membatasi penguasaan asset secara kuantitas melainkan membatasinya dengan cara. Demikian koreksi Islam terhadap konsepsi kepemilikan dalam kapitalisme dan sosialisme.

Keempat, mengganti teori-teori yang berada pada sub sistem agribisnis yang bertentangan dengan Islam. "Mengganti teori" berlaku bagi teori-teori yang bertentangan dengan Islam; dan sudah tidak bisa diperbaiki lagi; serta Islam tidak bisa dan tidak akan menggunakan teori tersebut sama sekali. Dalam pandangan kapitalisme, misalnya, kehidupan ekonomi suatu bangsa dianggap aman jika tercapai pertumbuhan secara kuantitas, serta terpeliharanya stok kebutuhan yang sebanding dengan jumlah penduduk. Jika terdapat sejuta orang penduduk, maka stok pangan yang ada harus mencukupi bagi jumlah penduduk tersebut. Adapun kemampuan individu untuk memperoleh kebutuhannya tergantung pada ketersediaan dana pada masing-masing individu tersebut, sehingga tidak heran walaupun stok aman, terdapat orang yang kelaparan.

Dalam pandangan Islam, sebagai pengganti pada teori tersebut, keberhasilan ekonomi dalam suatu komunitas (atau warga negara) bukan hanya adanya pertumbuhan dan tersedianya stok untuk waktu tertentu yang sebanding dengan jumlah penduduk melainkan harus terpenuhinya kebutuhan individu. Yang menjadi perhatian bukan terpenuhinya kebutuhan sebuah komunitas melainkan terpenuhinya kebutuhan individu per individu. Seandainya sebuah negara memiliki stok pangan yang aman, tetapi jika masih ada seorang warga negara yang kelaparan, maka negara tersebut belum disebut sebagai sebuah negara yang berhasil.

Kelima, melakukan kreasi teori-teori baru yang betolak dari sudut pandang Islam, yang sampai kini belum menjadi perhatian para "ideolog" lain, seperti kapitalisme dan sosialisme. Para ilmuan modern, misalnya, sangat kreatif untuk merumuskan berbagai indikator untuk mengukur terpenuhinya kebutuhan individu dalam sebuah negara. Demikian hanya, pandangan kapitalis sangat memperhatikan pertumbuhan ekonomi, tetapi dalam waktu yang sama terjadi kesenjangan. Sebaliknya, sudut pandang sosialis sangat memperhatikan pemerataan, tetapi gagal mencapai pertumbuhan ekonomi. Karena itu, bertolak dari ajaran Islam yang memancar dari akidah Islam, para ilmuan muslim harus berhasil mencapai pertumbuhan sekaligus pemerataan dengan berbagai pendekatan yang bersifat individual.

\section{KESIMPULAN DAN IMPLIKASI KEBIJAKAN}

Kesimpulan 
Pendekatan syariah terhadap berbagai sub sistem agribisnis memberikan kritisisme berbasis spiritual yang sangat tajam, di samping memberikan alternatif pembangunan pertanian. Di antara alternatif yang dapat diberikan adalah sebagai berikut:

1. Agribisnis syariah menyetujui pemberian subsidi bagi pengadaan saprotan sebagai bagian dari pengadaan pangan yang merupakan pemenuhan kebutuhan pokok warga negara yang menjadi tanggung jawab negara.

2. Adanya konsepsi kepemilikan merupakan alternatif srategis bagi pengadaan dana yang diperlukan untuk memberikan subsidi bagi sektor pertanian, di mana dana tersebut dapat bersumber dari asset yang masuk kategori kepemilikan umum.

3. Untuk setiap sub sistem agribisnis yang tidak terkait dengan ideologi atau keyakinan, maka konsepsi syariah memberikan keterbukaan untuk mengadopsi, mengembangkan, dan bekerjasama dengan berbagai pihak, baik muslim atau non-muslim.

4. Dalam mengadopsi teori-teori yang netral, agribisnis syariah akan melakukan internalisasi kesadaran ketuhanan, sehingga sebuah teori yag netral dan keterampilan teknologis tidak kehilangan koneksitasnya dengan kesadaran ketuhanan.

\section{Implikasi Kebijakan}

Sejalan dengan kesimpulan yang merupakan dasar-dasar pemahaman terhadap agrribisnis syariah, maka terdapat beberapa hal penting yang berimplikasi pada kebijakan pembangunan pertanian, yaitu:

1. Perlunya pembehanan konsepsi kepemilikan secara implementatif untuk menata asset-asset strategis di
Indonesia yang akan berimplikasi pada kesejahteraan dan kemandirian petani.

2. Dengan bersumber pada dana yang berasal dari kepemilikan umum, Pemerintah dapat mengembangkan SDM petani, penguatan kelembagaan petani, memperkuat riset dasar bagi kemandirian petani yang akan bermuara pada keamanan dan kedaulatan pangan.

3. Pemerintah dapat memberikan subsidi dalam bentuk bantuan langsung permodalan pada petani yang sudah terbina, baik kualitas SDM-nya maupun kelembagaannya.

4. Pemerintah dapat memperkuat aspekaspek penunjang ssitem agribisnis yang ditopang oleh SDM petani dan pendanaan yang memadai.

5. Namun perlu adanya kajian lanjutan mengenai potensi dana bagi pembangunan pertanian yang bersumber dari kepemilikan umum tersebut.

\section{DAFTAR PUSTAKA}

An-Nabhani, Taqyuddin. An-Nidzam alIqtishody (Beirut: Dar alBayariq, Edisi Revisi 2004).

Bremmer, Ian, The End of Free Market, edisi Bahasa Indonesia terjemahan Alex Tri Kantjono Widodo (Jakarta: Gramedia, 2011).

Callinicos, Alex, Sembilan Tesis Anti Kapitalisme, (Yogyakarta: Multi Solusindo, 2011).

Bordenave, Juan Diaz"Komunikasi Inovasi Pertanian di Amerika Latin," dalam Everett M. Rogers (ed.), Komunikasi dan Pembangunan: Perspektif Kritis, terjemahan Dasmar Nurdin (Jakarta: LP3ES, 1998). 
Fahd, Toufic, "Botany and Agriculture," dalam Roshdi Rashed (ed.), Encyclopedia of The History of Arabic Science (London and New York: Routledge, 1996).

Holid, Sobran, Kompasiana.com, 12 Februari 2011.

Rogers, Everett M., Communication and Development: Critical Perspective, edisi Bahasa Indonesia terjemahan Dasmar Nurdin (Jakarta: LP3ES, 1989).

Said, Endang Gumbira dan Yayuk Eka Pratiwi, Agribisnis Syariah: Manajemen Agribisnis dalam Perspektif Syariah Islam (Jakarta: Penebar Swadaya, 2005).

*Ujang Maman (mamankh2002@yahoo.com) adalah Dosen di Fakultas Sains dan Teknologi
Said, Endang Gumbira dan Harits Intan, Manajemen Agribisnis (Jakarta: Ghalia Indonesia, 2001).

Strahm, Rudolf H., Kemiskinan Dunia Ketiga, Menelaah Kegagalan Pembangunan di Negara Berkembang (Jakarta: PT Pustaka Cidesindo, 1999).

Sunarto, Kamanto, Pengantar Sosiologi (Jakarta: Lembaga Penerbit Fakultas Ekonomi Universitas Indonesia, 1993).

Vernon Katz, Lilian."Characteristics and Background of Enterpreneurs," dalam Robert D. Hisrich dan Michael P. Peters (eds), Entrepreneurship: Starting, Developing, and Managing a New Enterprise (Boston: Richard D. Irwin, Inc., 1992).

\footnotetext{
UIN Syarif Hidayatullah Jakarta
} 